\title{
THE RHETORIC OF FAMILIARITY AND CONTEMPT IN JOB 2:9-10
}

\author{
Mayer I Gruber \\ Department of Bible and Ancient Near East \\ Ben-Gurion University of the Negev, Beersheva \\ Israel
}

\begin{abstract}
Responding to my 1998 article "Three Failed Dialogues from the Biblical World," Professor Moshe Greenberg suggested that by translating the imperative mut in Job 2:9 "Drop dead" I offended Job's wife, Hebrew Scripture, and my readers. The offense was to make Job's wife speak not the language of higher education but that of a fishwife or wastrel. In fact, both Greenberg's defence of Job's wife and my attribution to her of foul language are strongly represented in biblical translation and exegesis from antiquity to the present. Moreover, the examination of the history of the interpretation of both Job's wife's use of the imperative mut and of Job's referring to her words as appropriate to one of the nebalot shed important light on the rhetoric of familiarity and contempt. This subject is certainly most appropriate for an essay in honor of the foremost scholar of biblical rhetoric, Yehoshua Gitay.
\end{abstract}

In my article, "Three Failed Dialogues from the Biblical World," I I translated the imperative mut spoken by Job's wife at the end of Job 2:9 "Drop dead." Responding to this article, my revered teacher, Professor Moshe Greenberg, wrote as follows [my translation from the Hebrew]:

When you formulate a summary of Job's wife's advice to him by means of the expression "Drop dead" the reader senses a sudden departure from the language register of an article addressed to university educated people to the language register of wastrels. ... I felt embarrassed for you when I read this expression. I experienced the unpleasant sense of one who shares the embarrassment of a close relative. Without a doubt, the audience of your readers did not expect such crass language, especially insofar as Job's wife spoke out of a severe crisis of faith. The English expression, on the other hand, expresses in gross exaggeration, "Leave me alone with your nonsense/Go away from here." Such a manner of speech is to curse someone who is loathsome to you. Whoever makes Job's wife speak in such a manner turns her into an incongruous image - on the one hand an honorable person of worthy ancestry and at the same time one who speaks like a fishwife. ${ }^{2}$

Job himself refers to his wife's outburst by saying, "You have spoken as one of the nebalot women would speak" (Job 2:10). The Medieval Aramaic Targum found in the Rabbinic Bible understands nebalot in Job 2:10 as denoting "women who engage in sexual relations while they are still living in their father's home."3 I wondered, therefore, "What is the

1. Gruber, Mayer I, "Three Failed Dialogues from the Biblical World, "Journal of Psychology and Judaism 22 (1998), p. 57.

2. Personal written communication dated December 18,1998 , in an exalted Hebrew style worthy of Abba Eban, Hayyim Nahman Bialik, or Isaiah son of Amoz.

3. In Gen. 34:7 and 2 Sam. 13:12 the abstract noun nebalah designates pre-marital sexual activity. Notwithstanding the fact Tamar is Amnon's half-sister, she suggests to Amnon in 2 Sam. 13:12-13 that he should not engage in nebalah and should thus not be one of the nebalim 'men who engage in pre-marital sex'. On the 
source for Prof. Greenberg's view that Job's wife should be made to speak in the manner of a distinguished scholar delivering an academic lecture?" Obviously, the source of Greenberg's view of how Job's wife should speak is not the Medieval Aramaic Targum, which associates a loose tongue with loose morals. It is equally obvious that the source of Greenberg's view of how Job's wife should speak is not the famous Saint Augustine who refers to Job's wife as diaboli adjutrix 'Satan's assistant'.

The reason for Augustine's most appropriate labeling of Job's wife as 'Satan's assistant' is the fact that, wittingly or unwittingly, she encourages Job (Job 2:9) to do exactly what Satan said that Job would do and what God rightly contended Job would not do, namely, "curse God" (Job 1:11; 2:5; 2:10). Satan set out to prove to God that indeed if God made Job suffer he would curse God (Job 1:11). Satan did not know, perhaps, what the all-knowing narrator informed us in Job 1:5, namely, that Job was obsessed with avoiding culpability for the cursing of God. Indeed, Job worried that perhaps in the course of a series of parties his children might have become so inebriated that they had unwittingly cursed God "in their hearts." For this reason, Job habitually offered sacrifices at the end of his children's seasonal partying for the atonement of any such sin. Similarly, many Orthodox Jews to this day observe a series of three fasts on successive Mondays and Thursdays in the fall and in the spring lest in the course of observing the joyous festivals of Tabernacles and Passover respectively they may have in the midst of their inebriation violated some minor halakah. ${ }^{4}$

It is not fortuitous, therefore, that the narrator informs us in Job 1:21 that Job responded to the tragic death of his three daughters and seven sons by blessing rather than cursing God: "The LORD gave; the LORD took back; blessed be the Name of the LORD." In fact, this vindication of God's trust in Job and demonstration that Satan was mistaken in predicting that Job would, indeed, curse God are reminiscent of the surprise of King Balak of Moab, who commissioned Balaam to curse Israel only to discover that Balaam had blessed Israel (Num. 24:10).

When the annihilation of Job's children, livestock, servants and movable property does not prompt Job to curse God, Satan suggests that if God would let Satan afflict Job himself with a disease, then certainly Job would curse God (Job. 2:5). God and Job are, in fact, fully vindicated by the report in Job 2: 10, "Despite all of this Job did not sin with his lips." The latter declaration follows upon the attempt of Job's wife to get Job to do what all the diabolical schemes of Satan failed to accomplish. Indeed, she said to him, "Curse God, and die." Had Job followed this, what some people would call 'well-meaning advice', just at the point where Satan would have to admit to God that Satan was wrong; God was right; and Job's integrity is not the ephemeral reflection of his wealth and status, God would have lost the wager. Rightly, therefore, did Augustine characterize Job's wife in this context as 'Satan's assistant'.

contrary, she says in 2 Sam. 13:13b, "Now, please speak to the king [our father, asking my hand in marriage] for surely he will not withhold me from you." It is on the basis of the etymological relationship of the plural noun nebalot in Job. 2:10 with the singular noun nebalah in Gen. 34:7 that ancient Rabbinic exegesis and the medieval Job Targum identify Job's wife with Jacob's daughter Dinah, whose story is told in Gen. 34.

Concerning that narrative see Gruber, Mayer I, "A Reexamination of the Charges Against Shechem son of Hamor," Beit Mikra 24 (1999), pp. 119-127 (in Hebrew). Concerning Rabbinic exegesis of the Book of Job see Baskin, Judith R, "Rabbinic Interpretations of Job," in The Voice from the Whirlwind, edited by Perdue, Leo G and Gilpin, W Clark, (Nashville: Abingdon Press, 1992), pp. 101-110; see also Gruber, Mayer I. "The Book of Job," in The Jewish Study Bible, edited by Berlin, Adele and Brettler, Marc Zvi, (New York \& Oxford: Oxford University Press), pp. 1499-1562.

4. Arukh, Shulhan, Hayyim, Orah; Chapter 492. The commentary Ba'er Heiteiv by Judah b. Simeon Ashkenazi, first published at Amsterdam in 1742 and commonly printed in the margin of Shulhan Arukh, Orah Hayyim to this day, anticipates our comparison of this custom with the narrator's account of Job's sacrifices in Job 1:5. 
The entire argument between God and Satan throughout Job 1-2 revolves around the question as to whether or not, God forbid, Job will curse God. ${ }^{5}$ It is understandable that Job would refer to her suggestion that he employ foul language (and thereby cause God to lose the wager) as the foulest of language, namely that appropriate to nebalot.

So where then does Prof. Greenberg derive his interpretation of Job 1-2 according to which Job's wife delivered a speech, whose language register was worthy of a Regius Professor of Hebrew? The answer, of course, is not in the Hebrew text of Job, which I discussed in my 1998 article. Prof. Greenberg's inspiration may well have been the Old Greek version of Job 2:9, which adds the following, which would seem to warrant the reader's total sympathy for the position advocated by Job's wife:

After much time had passed his wife said to him, "How long will you endure, saying, 'Behold, I shall wait a little longer, expecting the hope of my salvation.' Behold, your memory is already blotted out from the earth, the sons and daughters, the travail and pangs of my womb, whom I reared with toil in vain. And you sit in decay caused by worms, spending the nights outside, and I am a wanderer and a servant, going from place to place and from house to house, looking for the sun to set, in order that I might rest from my toils and pains which now oppress me. But say some word against the Lord and die."

Greenberg's defense of Job's wife is also anticipated in modern times by Ernst Wilhelm Hengstenberg (1802-1869), who writes as follows in his Lecture on the Book of Job:" "Her desperation proceeds from her strong love for her husband; and if she had to suffer the same herself, she would probably have struggled against despair."8 Having quoted Hengstenberg only to ridicule his thesis, Delitzsch himself argues:

Job has lost his children, but this wife he has retained, for he needed not to be tried by losing her; he was proved sufficiently by having her. She is further on once referred to, ${ }^{9}$ but even then not to her advantage. Why, asks Chrysostom, did the devil leave him this wife? Because he thought her a good scourge, by which to plague him more acutely than by any other means. Moreover, the thought is not far distant, that God left her to him in order than when, in the glorious issue of his sufferings, he receives everything doubled, he might not have this thorn in the flesh also doubled. What enmity towards God, what uncharitableness towards her husband, is there in her sarcastic words, which, if they are more than mockery, counsel him to suicide! (Ebrard). But he repels them in a manner becoming himself. ${ }^{10}$

Nevertheless, the late Israel Prize Laureate Meir Weiss argues as follows in defense of Job's wife's call for Job to curse God and die:

5. In a baraitha [probably taken from a version of Tosefta, Abodah Zarah 9:4] quoted in Babylonian Talmud, Sanhedrin 56a the prohibition against cursing God is the second in the list of seven precepts incumbent upon all civilized people (the Noahide laws).

6. English rendering of the Old Greek version of Job 1:9 taken from Hartley, John E, The Book of Job, New International Commentary on the Old Testament (Grand Rapids: Eerdmans, 1988), p. 83.

7. The original publication is Hengstenberg, Wilhelm, Ueber das Buch Hiob: ein Vortrag (Berlin: Schlawitz, G, 1856); a complete English translation of the lecture is contained in id., Commentary on Ecclesiastes, translated by Simon, DW, (Edinburgh: T \& T Clark, 1860).

8. Quoted from Delitzsch, Franz, Biblical Commentary on the Book of Job, translated by Bolton, Francis, (2 vols; Edinburgh: T \& T Clark, 1866), vol. 1, p. 71.

9. Delitzsch refers to Job 19:17 (see Delitzsch, p. 70). Apparently, Delitzsch forgot about Job 31:9-10; on the latter passage, see below.

10. Delitzsch, Biblical Commentary on the Book of Job, vol 1, pp. 71-72. 
It appears that her suggestion to her husband is identical to what Satan said about Job, but her motivation is different. Satan speaks out of pure apostasy; Job's wife speaks out of pity. This is evident from the one "original" word in her speech: the verb wamut "and die", which indicates the purpose of her advice, different from that of Satan. Satan wishes to prove that Job serves God only in order to receive reward. Job's wife wishes Job to be relieved of his suffering. Her intention is good; her action is not. Job - at least this time - does not understand his wife, and takes her words, not as she intends, but literally. Job's wife unwittingly becomes partner to Satan. ${ }^{11}$

Morevover, even Weiss understands Job's action as a reprimand, and he translates nebalot as "shameless women" not as "professors who speak the Queen's English".

Interestingly, Weiss' interpretation of the words of Job's wife as beneficial in intent but wholly misunderstood and unappreciated by Job is fully anticipated by Rabbenu Tam (late $11^{\text {th }}$-early $12^{\text {th }}$ centuries C.E.):

\section{Curse God and Die}

Satan put this evil advice into the heart of his wife in order to lead him astray so that perhaps he [Job] might be tempted so that he [Satan] would win out over him. She, however, meant well for she thought, "Even though you do not have it in your heart to curse [God] out of your anger because you are a paragon of virtue, curse God so that he will kill you (it is the same euphemistic usage [of the verb brk 'bless'] as is attested in "Naboth cursed God" [1 Kgs. 21:13]) for this [cursing] is a misdemeanor and more likely than any other of the sins that might occur to a person who is abandoned and full of rage."

\section{You speak like one of the nebalot}

The Fools. It is the same meaning [of the root $n b l$ ] which is reflected in "You are acting like a total fool" (Ex 18:18) ${ }^{12}$ for even though she spoke out of wisdom Job took her for a fool. Now there is [in Biblical Hebrew] nebalah meaning 'foolishness' as in "You are acting like a total fool"; and there is nebalah which denotes fornication [Heb. ni'up] as in "He has performed an act of fornication [Heb. nebalah] in Israel" (Gen. 34:7); and there is nebalah which means 'mock someone' as in "A son mocks his father" (Mic. 7:6), and [there are] many other meanings. ${ }^{13}$

In other words, in Rabbenu Tam's reading, as in Weiss' reading, Job's wife speaks in the language of academic discourse, like Satan and other speakers in the Book of Job. Job, on the other hand, (mis)understands her as speaking like a fishwife or, worse still, like a woman of loose morals (Targum). How does this happen?

There are three possibilities. One is that with all due respect to the Old Greek, Rabbenu Tam, Meir Weiss, and my revered teacher, Prof. Greenberg, Job, who lived with his wife long enough to beget and raise seven adult children, may have understood the proper

11. Weiss, Meir, The Story of Job's Beginning (Jerusalem: Magnes Press, 1983), p. 70.

12. This is an idiosyncratic interpretation of Jethro's rebuke of Moses in Ex. 18:18, which is usually understood not as a derivative of a root $n b l$ but as the derivative of a root bly denoting 'wear out'; see, e.g., KJV: "Thou wilt surely wear away."

13. My translation of the two passages from the Commentary on Job by Rabbenu Tam is based on the Hebrew text (according to Ms. Oxford Opp. Add. fol. 22 and Ms. Rostock Cod. Or. 33) published in Avraham Shoshana, The Book of Job with the Commentaries of RaSHI, Rabbenu Jacob b. Meir Tam, and a disciple of RaSHI (Jerusalem: Ofeq Institute, 1990), p.14 (in Hebrew); for extensive modern literature on the nuances of the noun nebalah and its cognates in Biblical Hebrew see Clines, David JA, Job 1-2, Word Biblical Commentary (Dallas: Word Books, 1989), pp. 53-54. 
exegetical tradition to apply to his wife's utterances. This is to say that Job may have responded to his wife's intonation and nonverbal cues such as gestures, postures, and facial expressions. ${ }^{14}$ The result is that, like an outsider, who is oblivious to these cues, the aforementioned exegetes would say to Job, "What she meant was..."; "Job, you are only imagining that she wants you to die; maybe she was only joking"; "Why do you think that she meant you harm when she asked you to make Satan the winner of his wager with God? Surely she meant well." Unfortunately, we all know people who make light of our being upset when someone tells us that she or he wishes that we would die or suffer a fate worse than death.

A second possibility is that, indeed, Job's wife meant well. However, since Job did not yet have the benefit of writings on communication by John Gray and Deborah Tannen, he really did misunderstand her. Indeed, there is evidence elsewhere in the Book of Job that Job had yet to learn how to treat his wife and her utterances with love and respect. In Job 19:17 Job himself reports, "My odor is repulsive to my wife." Indeed, the disease Job suffered from made him repulsive. But surely, a marriage made in heaven makes it possible for spouses to care for each other in sickness and in health. ${ }^{15}$ It would appear, therefore, that whether Job's wife meant to insult him or he took her kind and thoughtful utterance as an insult, the husband and wife in question were having serious communication problems. Finally, it should be recalled that in his confession of innocence in Job 31 Job suggests that if, God forbid, he had ever been attracted to someone else's wife and lay in wait for her at the neighbor's door, he should repay the offense by having his wife perform sexual favors for other men. Obviously, a reader with the most elementary sensitivity would have to ask, "What other than tell him to drop dead when he was both ill and bereft (Job 2:9) and to avoid his company when he was sick (Job 19:17) had this poor woman ever done to him that he would try to atone for his lustful thoughts by having his wife be treated as a sex object?" One answer might well be that, indeed, Job and his wife were having serious communication problems reflected first in his misunderstanding her in Job 2:10 and again in his description of her behavior in Job 19:17 and finally in his thinking of her as a mere sex object in Job 31:9-10.

A third possibility has been suggested by Weiss and earlier by Rabbenu Tam. This alternative is that neither Job nor his wife really means the things each one says. They only mean well. ${ }^{16}$ The upshot, of course, of speaking insensitively and thoughtlessly to and about the people closest to us is that we poison our immediate environment and our primary relationships. It is often said that familiarity breeds contempt. Contempt, on the other hand, is not a breeding ground for familiarity.

14. On the importance of these cues in human communication see Gruber, Mayer I, Aspects of Nonverbal Communication in the Ancient Near East, Studia Pohl 12 (2 vols.; Rome: Biblical Institute Press, 1980), vol. 1 , pp. 6-8 and the literature cited there.

15. Lest it may occur to a reader that emotional bonding and mutual respect and concern between husband and wife were foreign to the ancient Near Eastern setting of the Book of Job, the reader is referred, inter alia, to the love and concern for her beloved King Zimri-Lim expressed in the impassioned letters penned to him by Queen Shibtu, who was only one of his several devoted wives. Concerning the letters sent by Queen Shibtu to her husband, King Zimri-Lim of Mari (1775-1761 B.C.E.) see, inter alia, Batto, Bernard Frank, Studies on Women at Mari (Baltimore \& London: Johns Hopkins University Press, 1974), pp. 8-20.

16. Interestingly, a relative reported the following: "A neighbor was diagnosed as suffering from a life-threatening illness, from which, thank God, he was cured. This person's wife was wont to mouth the rhetorical question, 'Don't you think everyone means well?' I assume that this rhetorical question means that the person posing this question holds that everyone actually means well. Consequently, I asked someone who was praying for the speedy demise of the latter woman's husband if indeed she meant well. Her reply was an emphatic 'No'." 
Perhaps, Job - a veritable paragon of virtue - God says so at the book's beginning and end - and his beloved life partner misbehaved and needed to be taught by John Gray, ${ }^{17}$ Deborah Tannen, ${ }^{18}$ or perhaps the master of biblical rhetoric, Yehoshua Gitay - how much better life might be with just a little consideration for the feelings of others. If so, how much more can all of us who live in the modern world of John Gray, Deborah Tannen, and Yehoshua Gitay appreciate the fact that rationalizations of other people's verbal misbehavior such as "He/she meant well"; "You simply misunderstood" are no longer acceptable at home, in the academy, or even where you go to buy fish.

Moreover, when the plain sense of Hebrew Scripture cries out to us in its portrayal and denigration of the rhetoric of contempt, it is right and our bounden duty as biblical scholars to pay attention and to bring the timeless lessons to bear on our teaching and writing. To gloss over and apologize is to miss our calling and, in the words of Job in Job 12:7, to speak wickedly, as it were, on behalf of God. Of such eisegetes Job warns, "He [God] will surely reprove you" (Job 12:10).

17. See Gray, John, Mars and Venus: Together Forever: Relationship Skills for Lasting Love (New York: Harper Perrenial, 1996); Men are from Mars: Women are From Venus (New York: HarperCollins, 1992).

18. See Tannen, Deborah, You Just Don't Understand: Women and Men in Conversation (New York: Ballantine Books, 1990); id., That's Not What I Meant! (New York: Ballantine Books, 1986). 